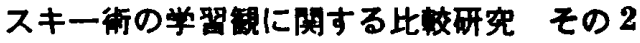

- Österreicher Schi-Lehrplan SKI ABC Technique Moderne の比較研究

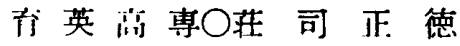

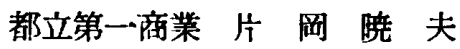

都立立川高校 案 田 陽 義

序前年の研究で，我々は学習のさせ方の記述によ つて捕えた学習観を提示した，学習観の相違は教程に於 て，牛徒に対する態度の違い葆示す教材の配列及び教材 の利用治:の相違を寺さであろう，本件は，(1)教材の配列 の相達，(2)教材の利用の仕方の相違を “Österreicher Schi-Lehrplan" "SKI ABC Technique Moderne" によつて捕えて提示する。

轺諳 “SKI ABC Technique Moderne”では幾 つかの動作をある段階までに獲得した能力のあるスキー ヤーは，ある教材の配列部分を通り越してよいと云ら教 材の配列がされてある。これは他にない特徵である。こ こでは教材は動作を身につけるための手段と考えられ， その作用で配列している，維杪の全てがこの様にして配 列されているのではない，しかし教程が最終目標を， Christiania moderne と Godille に置き，その上に競 技の練酱を組又入れる系列として考えられていること
け，教材が牛徒に働きかける作用を中心に置いて考え， 配列してある忙を示与，又その利用法が，理解，停止位 谓で練酱与る，火行と云う過程で表現されているのは， 学習の進行に対する明確なすじ道を一つ示した事に他な らない。これらから，生徒は教材を通じて明確に示され た動作を理解し，停止で練習し，実行する事で技術の警 得に必要な動作を身につけて行く．そして能力のある者 は技術の獲得が速に行なわれる，他方 “Österreicher Schi-Lehsplan”に於ては，各種目は教材の中に含ま れ，教材は生徒が獲得すべき日標であり，種目の省略は 許されない，しかも Fortbildung は Grundausbildung ですでに獲得した技術をみがき上げる，新しい種 目を獲得する，それらを基楚として実際に用いる，と三 つの目標を持つている.これらは教材を，文化財として の価值を持つものと云う見方で捕えている事を示し，こ のことが教材の配列を直線的な発展と云う形でなく，各 教材が文化財としての価值を持ち，各找術を目指してい る配列，そしてみがき上げの段階を持つ配列となつて現 われてくる，教柯の利用に閣しては，実際の生活で行な らのと同じである．生徒は文化財としての種目を，斜 面, 雪質, 動作の回数と量, 環境の変化等を利用して身 につけ, みがきトげていく。

\section{スキー衡の技街表現に関する比较研究 (2)}

\section{Österreichischer Schi-Lehrplam と SKI ABC de Georges Jondert Jean Vuarnet $の$ 比校}

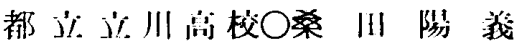
都主第一淌等学校

青 英 向専乼司 正 徳

身体連動の現象を，伝達を目的として客観的に記述す るには，身体各部位の名称を媒介にしなければならな い. 身体の運動現象は有機的なつながりを持ち，各運動 部分の相互関係は複雑である，それをどの身体部位の表 象によつて記述するか，定つた方法はない，そのため， 同一の運動現象も表象のしかたによつて，差が現れるの ではないかと考えられる。すし表象の方法に違いが出る 場合，それはどのような理由によるかが問題である．何 によつてその運動睍象を表象するか，基準になるるのが あるのではないかと考えられる. それは例えば，(1)生理 的に合理的である. (9力学的に合理的である. (2学習の 効果を高める. (4)学習観による. (5)感覚的に理解しやす い. …...等である. 昨年度は表象について明らかにしょ らと, 同し運動現象を最高の技能として記述されたオー ストリーとフランスのスキー技術書の和訳書によつて比
较した。その絬果，表象に用いる身体部位の用い力に違 いがあることがわかつた，今间は更にそれらの各部位 が，どの上らな楎動をするかを原書によつて此較した。 一江は、各部伦の名称に刘し連動を意味する単語を選 び，出詞にはとらわれず，どのような運動垷象を示して いるかを愉訫した。その結果，二つのスキー術に現れた 主な違いは，足については，オーストリーでは脚全体の 運動や姿勢の表象に用い，フランスでは身体の支持点之 して用いている，次にカカトを示す言葉はフランスには ない。オーストリーでは，カカトによつて脚の軸を中心 とした|叮転運動，即ち“ねじり”と，股関節を軸とした 脚の側方えの運動を現している．腰については，オース トリーでは腰を上体の一部とみなし，股関節の運動によ $\eta$ ，脚部の屈伸と上体の mars の傾きや縦軸に対する 回転運動を現している. フランスでは mass としての 腰の移動運動（山側への）を示している.

結諭 オーストリーでは脚の運動の表象を足の部分 で行なう。これは体を中心にした運動であり，生活実践 的である。これに対しフランスでは脚を動かすのに，上 体の部分である腰を動かす方法をとる．この二つの違い は，スキー術の学習観に関する比较研究の結果と一致す るのではないかと考えられる。 